\section{JURNAL ABDIMAS

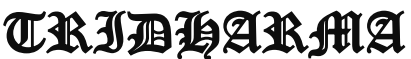

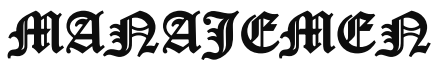

P-ISSN 0000-0000, E-ISSN 0000-0000

Jurnal ABDIMAS Vol. 1,No.1, Agustus 2019, Hal (22-26)

@Prodi Manajemen Fakultas Ekonomi Universitas Pamulang

Email: abdimasjurnal.unpam@gmail.com Telp: (021) 741-2566

\title{
MOTIVASI UNTUK MENINGKATKAN PRESTASI BELAJAR SEHINGGA MEMILIKI KUALITAS PENDIDIKAN YANG BAIK UNTUK MENGHADAPI KOMPETENSI DI DUNIA KERJA DI SMK DARUSSALAM, CIPUTAT, TANGERANG SELATAN
}

\author{
Aria Aji Priyanto,Wirawan Suryanto, Ratna Dumilah, Supardi \\ DosenEkonomi Fakultas Ekonomi Universitas Pamulang \\ Email aria.aji@gmail.com, dosen02244@unpam.ac.id, \\ dosen02209@unpam.ac.id, supardi@gmail.com
}

\begin{abstract}
ABSTRAK
Pengabdian ini berjudul Motivasi Untuk Meningkatkan Prestasi Belajar Sehingga Memiliki Kualitas Pendidikan Yang Baik Untuk Menghadapi Kompetensi Di Dunia Kerja Di SMK Darussalam, Ciputat, Tangerang Selatan.

Tujuan pengabdian ini adalah memberikan arahan terhadap Siswa dan siswi SMK Darussalam dalam menjalankan proses belajar mengajar disekolah, membuka wawasan serta paradigma siswa dan siswi SMK Darussalam untuk menghadapi jenjang pendidikan yang lebih tinggi dan bisa diterima dimasyarakat, memberikan semangat dan motivasi bagi siswa dan siswi SMK Darussalam untuk meraih prestasi yang baik, Memberikan wawasan agar siswa dan siswi SMK Darussalam dapat mempersiapkan diri dengan baik dalam menghadapi dunia kerja.

Metode kegiatan yang digunakan adalah memberikan seminar berupa presentasi, penyuluhan dan pelatihan di SMK Darussalam. Persiapan yang dilakukan adalah segala hal yang terkait dengan materi, bahan dan alat sesuai dengan tema secara baik. Hasil persiapan tersebut dimaksudkan agar materi tersampaikan dengan mudah dimengerti serta dipahami oleh para siswa dan siswi SMK Darussalam Ciputat, Tangerang Selatan. Kegiatan ini juga meliputi mendiskusikan bagaimana memberikan motivasi agar siswa dan siswi dapat memanajemen waktu dengan efektif dan efisien. Serta mendapat motivasi yang lebih dalam meningkatkan kualitas pendidikan agar selalu siap dengan keadaan yang ada di dunia kerja. Pada saat acara inti para siswa dan siswi SMK Darussalam di berikan penyuluhan yang mengacu pada peningkatan kualitas pendidikan dan kemampuan serta kesiapan para siswa dan siswi dalam menghadapi dunia kerja.

Kesimpulan dari pengabdian ini adalah para siswa dan siswi SMK Darussalam antusias dalam menerima ilmu baru, dan aktif dalam melakukan tanya jawab mengenai bagaimana cara meningkatkan kualitas dalam me-manajemen waktu serta kesiapan diri dalam menghadapi dunia kerja. Antusiasme tidak hanya terlihat dari siswa dan siswi SMK Darussalam tapi dari para guru di SMK Darussalam.
\end{abstract}




\section{JURNAL ABDIMAS

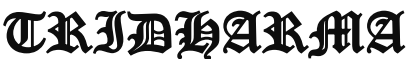

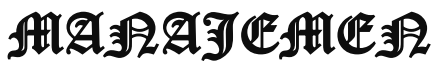

P-ISSN 0000-0000, E-ISSN 0000-0000

Jurnal ABDIMAS Vol. 1,No.1, Agustus 2019, Hal (22-26)

@Prodi Manajemen Fakultas Ekonomi Universitas Pamulang

Email: abdimasjurnal.unpam@ gmail.com Telp: (021) 741-2566

\title{
Kata Kunci: Prestasi Belajar, Kompetensi Dunia Kerja
}

\begin{abstract}
ABSTRAC
This dedication is titled Motivation to Improve Learning Achievement so that It Has Good Quality of Education to Face Competence in the World of Work in SMK Darussalam, Ciputat, South Tangerang.

The purpose of this service is to provide direction to students of SMK Darussalam in carrying out the process of teaching and learning at school, opening insights and paradigms of SMK Darussalam students to face higher levels of education and be accepted in the community, providing enthusiasm and motivation for students of SMK Darussalam to achieve good achievements, Provide insight so that students of SMK Darussalam can prepare themselves well in the face of the world of work.

The method of activity used is giving a seminar in the form of presentations, counseling and training in SMK Darussalam. Preparations made are all matters related to the material, materials and tools in accordance with the theme properly. The results of the preparation are intended so that the material is delivered easily understood and understood by students and students of SMK Darussalam Ciputat, South Tangerang. This activity also includes discussing how to provide motivation so that students and students can manage time effectively and efficiently. As well as getting more motivation in improving the quality of education to always be ready with the conditions that exist in the world of work. At the time of the core program the students of SMK Darussalam were given counseling that refers to improving the quality of education and the abilities and readiness of the students in dealing with the world of work.

The conclusion of this dedication is that students of SMK Darussalam are enthusiastic in accepting new knowledge, and are active in conducting questions and answers on how to improve quality in time management and self-readiness in facing the world of work. The enthusiasm was not only seen from students of SMK Darussalam but from the teachers at SMK Darussalam.
\end{abstract}

\section{Keywords:Learning Achievement, Competence in the World of Work}

\section{PENDAHULUAN}

Dalam perkembangan dunia pendidikan yang sangat pesat, kualitas pendidikan pun harus diperhatikan dengan baik, karena persaingan dunia kerja menuntut setiap orang harus memiliki banyak kemampuan yang baik dan berkualitas. Untuk meningkatkan kualitas siswa dan siswi mereka harus secara sadar dan mempunyai keinginan untuk belajar. Karena dalam proses belajar mengajar tidak hanya fasilitator yang baik untuk membuat kualitas itu namun juga harus diimbangi oleh niat dan keinginan para siswa dan siswi untuk belajar. Menumbuhkan minat dan rasa ingin 


\section{JURNAL ABDIMAS

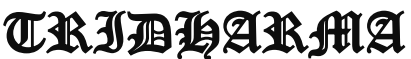

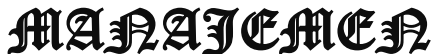

P-ISSN 0000-0000, E-ISSN 0000-0000

Jurnal ABDIMAS Vol. 1,No.1, Agustus 2019, Hal (22-26)

@Prodi Manajemen Fakultas Ekonomi Universitas Pamulang

Email: abdimasjurnal.unpam@ gmail.com Telp: (021) 741-2566 tahu sangatlah penting..Berbagai macam cara dalam proses belajar mengajar harus disiasati dengan baik, seperti pemberian materi yang tidak membuat bosan atau monoton, pemberian contoh yang mudah diserap sampai latihan soal yang dapat meningkatkan kompentensi. Proses belajar mengajar yang baik akan menyebakan hasil yang baik yang akan meningkatkan kompentensi kualitas sumber daya manusia untuk menunjang dunia kerja. Pengabdian masyarakat kali ini adalah tentang bagaimana menumbukan motivasi diri siswa dan siswi dalam meningkatkan prestasi belajar sehingga memiliki kualitas pendidikan yang baik untuk menghadapi kompentesi di dunia kerja.

Para siswa akan di beri wawasan mengenai proses pendidikan yang akan menumbuhkan minat belajar sehingga mereka akan mempunyai kualitas dalam menghadapi kompentensi di dunia kerja. Para siswa juga akan diberi arahan karena sebagian besar mereka masih ragu dalam memilih tujuan mereka setelah lulus sekolah. Untuk itu sudah menjadi tugas kita agar mereka memiliki kepercayaan diri dalam menentukan arah hidup mereka. Dengan adanya pemberian wawasan serta arahan yang baik tentang bagaimana bagaimana cara menentukan pilihan setelah lulus sekolah, lanjut pendidikan atau bekerja , Para pemikiran siswa menjadi terbuka dan mampu mengatur arah hidup mereka secara mandiri dan bermanfaat untuk orang lain. Oleh karena itu ,Perlu adanya dukungan dan pihak yayasan atau sekolah untuk menjalankan pelatihan ini agar tersampaikan dengan maksimalsehingga tujuan dari pengabdian masyarakat ini akan tercapai.

\section{PERUMUSAN MASALAH}

Dengan mempertimbangkan latarbelakang yang telah diutarakan diatas kami berinisiatif untuk membentuk pengabdian masyarakat bagi siswa dan siswi SMK Darussalam melalui presentasi, penyuluhan materi, dan pelatihan untuk meningkatkan prestasi belajar.

\section{TUJUAN PROGRAM}

1.Memberikan arahan terhadap Siswa dan siswi SMK Darussalam dalam menjalankan proses belajar mengajar disekolah

2.Membuka wawasan serta paradigm siswa dan siswi SMK Darussalam untuk menghadapi jenjang pendidikan yang lebih tinggi dan bisa diterima dimasyarakat.

3.Memberikan semangat dan motivasi bagi siswa dan siswi SMK Darussalam untuk meraih prestasi yang baik.

4.Memberikan wawasan agar siswa dan siswi SMK Darussalam dapat mempersiapkan diri dengan baik dalam menghadapi dunia kerja.

\section{METODE PELAKSANAAN}

Metode kegiatan yang digunakan adalah memberikan seminar berupa presentasi, penyuluhan dan pelatihan di SMK Darussalam. Pada hari pertama kita melakukan sosialisai kepada para siswa dan siswi SMK Darussalam mengenai apa yang akan kita lakukan dalam dua hari kedepan, 


\section{JURNAL ABDIMAS

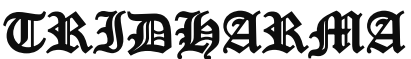

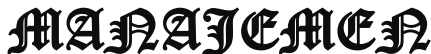

P-ISSN 0000-0000 , E-ISSN 0000-0000

Jurnal ABDIMAS Vol. 1,No.1, Agustus 2019, Hal (22-26)

@Prodi Manajemen Fakultas Ekonomi Universitas Pamulang

Email: abdimasjurnal.unpam@ gmail.com Telp: (021) 741-2566 yaitu presentasi dan penyuluhan mengenai menejemen waktu. Kemudian pada hari ketiga kami melakukan presentasi dan penyuluhan mengenai cara meningkatkan kualitas pendidikan. Dua materi ini kami pilih agar para siswa dan siswi SMK Darussalam siap dalam menghadapi dunia kerja.

Tim pelaksana kegiatan pengabdian pada masyarakat adalah dosen Fakultas Ekonomi jurusan manajemen sebanyak 10 orang. Tim pengabdian memberikan materi tentang Motivasi Untuk Meningkatkan Prestasi Belajar Sehingga Memiliki Kualitas Pendidikan Yang Baik Untuk Menghadapi Kompetensi Di Dunia Kerja Di Smk Darussalam, Ciputat,Tangerang Selatan.

\section{HASIL DAN PEMBAHASAN}

PengabdianMasyarakat (LPPM) Universitas Pamulang yang dilakukan oleh dosen-dosen program studi Manajemen telah berjalan dengan lancar dan mendapat sambutan hangat dari siswadansiswiserta guru SMK Darussalam Ciputat ,Tangerang Selatan.
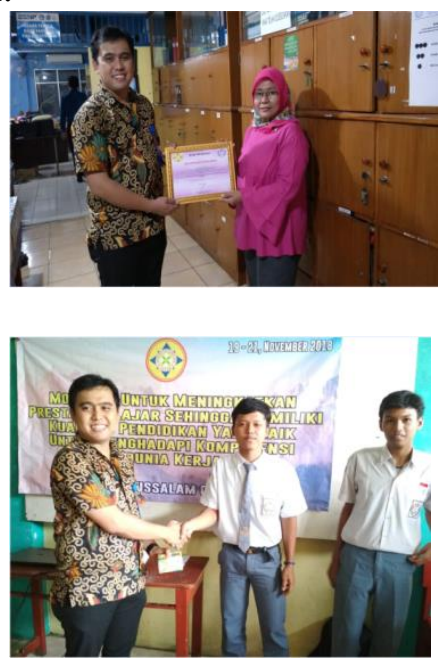

Harapan kami dengan

pengabdian ini dapatmenambahmotivasidalammeningk atkanpendidikansertadalammanajemen waktubagiparasiswadansiswi SMK Darussalam, agar siapdalammenghadapitantangan di duniakerja.

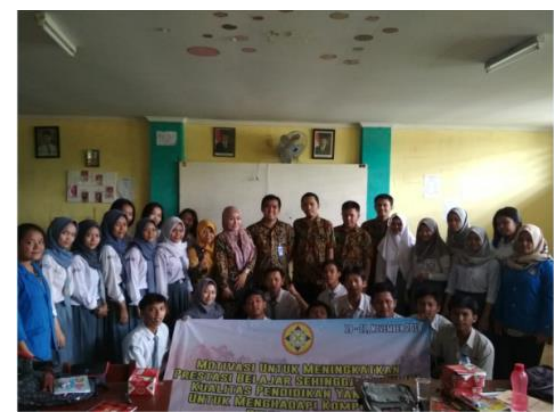

\section{KESIMPULAN DAN SARAN Kesimpulan}

Siswa dan Siswi SMK Darussalam sangat antusias dalam meningkatkan kemampuan yang mereka miliki dalam manajemen waktu dan peningkatan kualitas pendidikan, karena para siswa dan siswi SMK Darussalam dan menyiapkan diri mereka dalam menghadapi persaingan dunia kerja.

\section{Saran}

Setelah adanya pengabdian ini diharapkan peserta dapat memiliki kemampuan dalam manajemen waktu serta dalam meningkatkan kualitas pendidikan yang ada. serta mengajak teman/peserta agar dapat membagi ilmu dan kemampuan mereka dalam menghadapik dunia kerja.

\section{DAFTAR PUSTAKA}

A.M. Sardiman, 2001. Interaksi dan Motivasi Belajar Mengajar. Jakarta: Raja GrafindoPersada. 224 hlmn.

Abidin, Yunus. 2012. Pembelajaran 


\section{JURNAL ABDIMAS

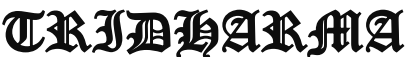

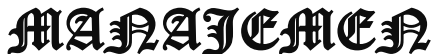

P-ISSN 0000-0000 , E-ISSN 0000-0000

Jurnal ABDIMAS Vol. 1,No.1, Agustus 2019, Hal (22-26)

@ Prodi Manajemen Fakultas Ekonomi Universitas Pamulang

Email: abdimasjurnal.unpam@ gmail.com Telp: (021) 741-2566
Bahasa Berbasis Pendidikan
Karakter.
Aditama.

Alam Handayani, Nizar dan Dody Hermana. 2008. Classroom Action Research. Rahayasa Research and training

Farida Rahim. 2008. Pengajaran Membaca di Sekolah Dasar. Jakarta : Bumi Aksara.

Handoko,T.Hani. 2012. Manajemen Personalia dan Sumber Daya Manusia. Edisi Ke-2. Yogyakarta: BPFE.

Hodgson, dalam Tarigan, 2008:7. Skripsi Indra Rakhman, Pembelajaran Membaca Pemahaman dikelas V SD Bandung, Tidak Diterbitkan.

Kridalaksana, Harimurti. 1982. Kelas Kata dalam Bahasa Indonesia. Jakarta: Gramedia Pustaka Utama.

L.Mathis., Robert dan John H.Jackson.Manajemen Sumber Daya Manusia. PT.Salemba 4. Jakarta. Edisi 10. 2006

Malayu Hasibuan S. P. 2012. Manajemen Sumber Daya Manusia. Cetekan keenam belas. Jakarta. PT. Bumi Akasara.

Mangkunegara, A.A Anwar Prabu. 2009. Manajemen Sumber Daya Manusia. Bandung: PT. Remaja Rosdakarya.

Mangkunegara.,Anwar Prabu. Manajemen Sumber Daya Manusia Perusahaan. PT.Remaja Rosdakarya. Bandung. Cetakan ke-12. 2013

Marwansyah. Manajemen Sumber Daya Manusia. CV Alfabeta. Bandung. 2010

Pasaribu, V. L. D., Susanti, F., \& Hartuti, E. T. K. (2019). MEMOTIVASI SISWA DAN SISWI SMK LETRIS

$\begin{array}{lrr}\text { INDONESIA } & \text { DI } & \text { DALAM } \\ \text { MENENTUKAN } & \text { PILIHAN } \\ \text { UNTUK } & \text { MELANJUTKAN } \\ \text { PENDIDIKAN } & \text { ATAU } & \text { BEKERJA } \\ \text { SETELAH } & \text { LULUS } \\ \text { SEKOLAH. Jurnal } & \text { Pengabdian } \\ \text { Dharma Laksana, 1(2), 161-172. }\end{array}$

Tampubolon, D.P. 1987. Kemampuan Membaca. Bandung: Angkasa.

Tim LPPM Pamulang. 2016. Buku Panduan Penelitian dan Pengabdian Kepada Masyarakat. Universitas Pamulang. Tangerang Selatan

Thobroni, M. 2016. Belajar Dan Pembelajaran. Yogyakarta: ArRuzz Media.

Sukiman dkk. 2016. Seri Pendidikan Orang Tua : Mendidik Anak di Era Digital. Kementerian Pendidikan dan Kebudayaan : Jakarta.

Syafi'ie, Imam. 1994. Terampil Berbahasa Indonesia I Petunjuk Guru Bahasa Indonesia. Jakarta : Departemen Pendidikan dan Kebudayaan 